\title{
ПРИЙОМИ ОБЧИСЛЕННЯ В КУРСІ МАТЕМАТИКИ ПОЧАТКОВОЇ ШКОЛИ
}

\author{
RUSLANA ROMANYSHYN, Candidate of Pedagogical Sciences, Associate \\ Professor of the Department of Specialist Methods and Technologies of \\ Elementary Education State Institution of Higher Education "Vasyl \\ Stefanyk Precarpathian National University", Ukraine
}

\section{CALCULATION METHODS IN THE MATHEMATICS OF PRIMARY SCHOOL}

\begin{abstract}
У статті здійснено теоретично-методичний аналіз проблеми формування усних обчислень та їх результату обчислювальної навички. Визначено загальні класифікації прийомів обчислення. 3'ясовано, що для виконання усних обчислень учень може використовувати не один прийом обчислення, а декілька відмінних за теоретичними засадами способів міркування.

У нашому дослідженні, дотримуючись груп приймів обчислення, виокремлених М. Бантовою та С. Скворцовою, до кожної групи прийомів ми віднесли ті прийоми, що вивчаються у початковій школі. Очевидно, що розглянугі прийоми пропонуються у курсі математики в певній послідовності, дотримуючись логіки розгортання змісту навчання. Так, у концентрі "Десяток" при виконанні обчислень школярі мають мати в арсеналі певні способи міркування: вони можуть діяти на підставі знання складу числа і суті арифметичних дій додавання i віднімання (перша група прийомів); при додаванні та відніманні числа 1 вони можугь діяти на підставі знання порядку слідування чисел в натуральному ряді (п'ята група прийомів); при додаванні і відніманні чисел першої п'ятірки діти можуть виконати обчислення частинами (шоста група прийомів); додавання чисел 6-9 можна здійснювати на підставі переставного закону додавання (друга група прийомів); відняти числа 6-9 можна на підставі взаємозв'язку арифметичних дій додавання та віднімання (друга
\end{abstract}

(C) Р. Романишин група прийомів). Окрім розглянутих нами обчислювальних прийомів, засвоєння більшості з яких є обов'язковими в курсі математики початкової школи, у перспективі наших досліджень убачаємо необхідність розгляду ще й прийомів раціональних обчислень.

Ключові слова: прийоми обчислення, початкова школа, обчислювальна навичка, теоретична основа прийому обчислення, класифікації прийомів обчислення, групи прийомів обчислення.

Summary. The article deals with theoretical and methodical analysis of the problem of the formation of mental calculations and their result computational skills. General classifications of calculation methods are determined. It has been found that to perform mental calculations a student may use not only one method of calculation but a number of ways of thinking different in theoretical foundations.

In our study, following the groups of methods of calculation identified by $\mathrm{M}$. Bantova and S. Skvortsova, we attributed to each group of techniques certain techniques that are studied in elementary school.

Obviously, the addressed methods are offered in the course of mathematics in a certain sequence, following the logic of expanding the content of learning. Therefore, in the Concentration "Ten" when performing calculations, students should have in the arsenal certain ways of thinking. They are as follows: They can act on the basis of knowledge of the composition of the number and the essence of the arithmetic actions of addition and subtraction (the first group of techniques); When adding and subtracting number 1 , they can act on the basis of knowing the order of the numbers in the natural sequence (the fifth group of techniques); When adding and subtracting the numbers of the first five, children can perform the calculations in parts (the sixth group of techniques); Addition of numbers 6-9 can be carried out on the basis of the permutation law of addition (the second group of techniques); One can subtract the numbers 6-9 based on the correlation of the arithmetic actions of addition and subtraction (the second group of techniques).

In addition to the computational techniques we have analyzed, most of which are compulsory in elementary school mathematics, we also consider the need of the methods of rational calculations in our research perspective.

Key words: methods of calculation, elementary school, computational skill, theoretical basis of calculation, classification of calculation methods, groups of calculation methods.

Мета: здійснити теоретичний аналіз прийомів обчислень у курсі математики початкової школи; дослідити їх класифікацію у методичній літературі; на основі здійсненого вивчення визначити прийоми обчислень, які належатимуть до відповідних груп.

Постановка проблеми в загальному вигляді. У початковій школі України учні опановують усні і письмові прийоми додавання, віднімання, множення і ділення в межах мільйона. Відповідно до Типових освітніх програм, створених під керівництвом О. 
Савченко (НУШ 1) та Р. Шияна (НУШ 2), у 1-2-му класах учні мають оволодіти обчислювальними навичками усного додавання та віднімання в межах 100; у 3-4-му класах - навичками усного додавання і віднімання круглих чисел у межах мільйона, множення i ділення в межах тисячі і навичками письмового додавання та віднімання, множення та ділення на одно-двоцифрове число (Типові освітні програми...). Очевидно, що для виконання усних обчислень учень може використовувати не один прийом обчислення, а кілька відмінних за теоретичними засадами способів міркування.

На сучасному етапі розвитку методичної науки вчені і вчителі впевнені у тому, що школярів потрібно ознайомлювати 3 різними обчислювальними прийомами з тією метою, щоб вони могли обрати найзручніший для себе (Skvortsova \& Romanyshyn, 2019, c. 2817-2829).

Логіка розгортання змісту навчання математики в початковій школі дозволяє реалізувати можливість поступового введення певних прийомів обчислення у міру ознайомлення учнів 3 певними теоретичними знаннями. Так, при вивченні додавання одноцифрових чисел з переходом через розряд у межах 20 на перших етапах відбувається перенесення та змінення відповідно змінених умов, відомого учням 3 концентру "Десяток", прийому додавання частинами. Опанувавши цей спосіб дії, вони вже не мають проблем 3 обчисленнями в межах 20, а також, можливо, і засвоїли склад чисел другого десятка. Тому на наступному етапі може траплятися такий випадок, коли учні вже не будуть вдаватися до подання другого доданка у вигляді суми зручних доданків, який реалізує прийом додавання частинами, а відразу на основі складу числа, поєднуючи частини в ціле, відтворюватимуть результат. Зауважимо, що на сучасному етапі розвитку початкової математичної освіти акцент на механічному заучуванні таблиць додавання в межах 20 не ставиться. Навпаки, програма орієнтує вчителя на формування обчислювальної навички, і можна очікувати, що, вправляючись у додаванні частинами, учні можуть мимовільно запам'ятати результати сум одноцифрових чисел, а це і склад чисел другого десятка. Тому на наступному етапі, розуміючи сугність арифметичної дії додавання як об'єднання двох множин без спільних елементів (об'єднання частин у ціле), школярі можуть уже не вдаватися до

\section{додавання частинами}

Крім того, ще в межах 10 першокласники з'ясували, що не зручно до меншого числа додавати більше, і навчилися виконувати обчислення у подібних випадках, застосовуючи переставний закон додавання. Прийом обчислення на основі переставного закону додавання може бути перенесений без змін на випадки додавання в межах 20, коли до меншого числа додають більше.

У міру засвоєння залежності суми від зміни одного 3 доданків є можливість ознайомити учнів 3 прийомом округлення при додаванні. У цьому випадку один 3 доданків - число 5, або 6, або, 7, або 8, або 9, замінюють близьким круглим числом 10 і обчислення виконують 3 числом 10, а потім від одержаного результату віднімають різницю між числом 10 і числом, яке замінили на 10. Практика свідчить про те, що навіть на даному етапі навчання в межах $20 \epsilon$ частина учнів, котра засвоює цей прийом і вважає його найзручнішим для себе.

У рамках проведеного дослідження ми спостерігали ситуацію, коли вчителька 2-го (2-В) класу Івано-Франківської спеціалізованої школи І-ІІІ ст. № 113 поглибленим вивченням англійської мови (2014-2015 н. р.) у процесі роботи за навчальними зошитами "Математика. 2 клас" С. Скворцової та О. Онопрієнко $з$ теми "Табличне додавання та віднімання чисел в межах 20" запропонувала учням прийом округлення. Лише 13,9\% (5 з 36 учнів) з них засвоїла цей прийом, а для решти він виявився складним. Учителька була дуже стурбована результатом, але у процесі спілкування ми наголосили на тому, що 3 прийомом округлення учні 2-го класу ще зустрінуться кілька разів - при додаванні та відніманні одноцифрового числа до/від двоцифрового і при додаванні та відніманні двоцифрових чисел. Тоді те, навіть хитке підгрунтя, яке було закладено в межах 20, дасть свої плоди. Припущення підтвердилося, про що свідчили результати контрольних усних обчислень та опитування учнів класу, яке проводила вчителька після кожного з етапів формування прийому округлення. Маємо такі результати: після вивчення теми "Табличне додавання та віднімання в межах 20" $22,2 \%$ (8 з 36 учнів) учнів засвоїло прийом, 16,7\% (6 з 36 учнів) назвало його найзручнішим для себе; після вивчення додавання та віднімання одноцифрового числа до/від двоцифрового - 27,8 \% (10 учнів); після вивчення теми "Додавання та віднімання двоцифрових чисел" - 38,9 \% (14 учнів). Маємо досить переконливу позитивну динаміку, водночас ці результати корелюють із спостереженнями інших учителів, які працюють за навчальнометодичним комплектом з математики С. Скворцової та О. Онопрієнко, у якому пропонується ознайомлення 3 різними прийомами обчислення (Скворияова \& Онопрієнко, 2013).

На сучасному етапі розвитку початкової математичної освіти існує тенденція формування в молодших школярів різноманітних прийомів усних обчислень. Очевидно, що автори навчально-методичних комплектів 3 математики - О. Гісь, Д. Філяк, Н. Листопад, С. Скворцова, О. Онопрієнко, Г. Лишенко, С. Тарнавська, К. Лишенко, В. Бевз, Д. Васильєва, С. Логачевська, Т. Логачевська, О. Комар, А. Заїка, М. Козак, О. Корчевська, підходять до цього питання по-різному.

Аналіз досліджень і публікацій. Зміст обчислювальних прийомів пропонуються в роботах М. Бантової, Г. Бельтюкової, М. Богдановича, О. Валльє, Л. Дашевської, Т. Демидової, О. Івашової, Н. Істоміної, Т. Кривошеї, I. Ліпатнікової, Г. Мартинової, М. Моро, Н. Нікітіної, О. Онопрієнко, Н. Рудовської, С. Скворцової, С. Степанової, Л. Сухіної, О. Тонких, Т. Фадєєвої, Т. Шевченко, В. Шпакової.

Виклад основного матеріалу дослідження. Слід зазначити, що існують класифікації обчислювальних прийомів М. Бантової та С. Скворцової (Бантова, 1993, с. 38-44; Скворичова, 2003, с. 45-53).

М. Бантова поклала в основу класифікації теоретичну основу, на якій базується прийом, і виокремила шість груп обчислювальних прийомів. Загалом дотримуючись класифікації обчислювальних прийомів М. Бантової, С. Скворцова виділяє такі ж групи прийомів обчислення, але дещо інакше розглядає групи обчислювальних приймів кожного класу (Бантова, 1993, с. 38-44; Скворичова, 2003, с. 45-53).

У нашому дослідженні вслід за М. Бантовою та С. Скворцовою ми класифікуємо прийоми обчислення, виходячи з їх теоретичних основ, i виокремлюємо також шість груп приймів обчислення:

1. Прийоми, теоретична основа яких у суті арифметичних дій.

2. Прийоми, теоретичною основою яких служать властивості арифметичних дій. 
3. Прийоми, теоретична основа яких - взаємозв'язки між взаємооберненими арифметичними діями.

4. Прийоми, теоретична основа яких - залежність результатів арифметичних дій від зміни одного з компонентів.

5. Прийоми, теоретична основа яких - питання нумерації чисел.

6. Прийоми, теоретична основа яких - правила.

Запропонована класифікація поширюється як на усні, так і письмові обчислювальні прийоми.

Характеризуючи прийоми обчислень, М. Бантова зазначила, що першими прийомами обчислень, які готують учнів до засвоєння властивостей арифметичних дій, $\epsilon$ прийоми, у теоретичній основі яких закладена суть арифметичних дій. До них дослідниця відносить: прийоми додавання і віднімання чисел у межах 10 для випадків виду а $+2, \mathrm{a}-2$, $\mathrm{a}+3, \mathrm{a}-3, \mathrm{a}+4, \mathrm{a}-4, \mathrm{a}+0, \mathrm{a}-0$; прийоми табличного додавання і віднімання 3 переходом через десяток у межах 20; прийом знаходження табличних результатів множення, прийом знаходження табличних результатів ділення (лише на початковій стадіi) і ділення 3 остачею, прийом множення одиниці і нуля.

Додавання і віднімання чисел першої п'ятірки доцільно здійснювати на основі знання складу чисел, тоді ці прийоми можна віднести до цієї групи (першої). Водночас додати або відняти числа 2, 3, 4 вдається і по частинах, застосувавши правило додавання суми до числа (сполучну властивість додавання), тоді їх слід віднести до другої групи прийомів. Це ж стосується і табличного додавання та віднімання 3 переходом через десяток у межах 20. Якщо учні заучують напам'ять ці таблиці, попередньо склавши їх за малюнком, то тут має місце застосування суті арифметичних дій додавання i віднімання, але якщо вони використовують додавання і віднімання по частинах, додавання на підставі переставної властивості, віднімання на підставі правила віднімання числа від суми або взаємозв'язку між діями додавання і віднімання, тоді ці прийоми слід віднести до другої та третьої груп прийомів за М. Бантовою.

Дослідниця пояснює виокремлення прийомів першої групи тим, що це перші прийоми обчислень, які вводяться відразу після ознайомлення із суттю арифметичних дій. Вони, власне, і дають можливість учням засвоїти конкретний зміст арифметичних дій, оск- ільки вимагають його застосування (Бантова, 1993, с. 38-44).

Ми ж, дотримуючись груп приймів обчислення, виокремлених М. Бантовою та С. Скворцовою, до першої групи відносимо наступні:

1) додавання та віднімання числа "нуль" до/від будь-якого числа, випадки коли учні розуміють число нуль як характеристику порожньої множини i при об'єднанні або вилученні множин застосовують це розуміння;

2) прийом додавання та віднімання чисел у межах 10 на підставі знання складу чисел і розуміння суті арифметичних дій додавання та віднімання;

3) прийом знаходження табличних результатів множення у випадку, коли учні вдаються до заміни множення арифметичною дією додавання;

4) прийом знаходження табличних результатів ділення у випадку, коли учні вдаються до заміни ділення дією віднімання, у результаті якого одержують число нуль;

5) ділення з остачею у випадку, коли учні вдаються до заміни ділення дією віднімання, у результаті якого одержують число, відмінне від нуля;

6) прийом множення числа "один" та "нуль" на будь-яке число, коли учні вдаються до заміни добутку сумою однакових доданків;

7) прийом позатабличного множення, коли учні вдаються до заміни добутку сумою однакових доданків;

8) прийом позатабличного ділення, коли учні вдаються до заміни ділення відніманням рівних чисел, у результаті якого одержують число "нуль".

Отже, якщо виконуючи додавання та віднімання чисел у межах 10 учень опирається на розуміння суті арифметичної дії додавання та віднімання, виходячи зі знання складу чисел у межах 10 та в межах 20, то в обчисленні застосовується прийом першої групи, але якщо учень вдається до переставляння доданків, до додавання та віднімання частинами, то він застосовує прийоми другої групи. Аналогічно і 3 множенням та діленням, діленням $з$ остачею тощо.

Група прийомів, теоретичною основою яких $\epsilon$ властивості арифметичних дій (друга група), характеризуються спільною схемою їх введення: спочатку вивчаються відповідні властивості, а потім на їх основі вводяться прийоми обчислень. До них відносять випадки додавання та віднімання чисел без переходу та 3 переходом через розряд $(2+8,54+20,54-20,27+3,27-$ $3,40-6,45-7,45+7,50+23,53-23,67+$
32, 67 - 32, 74 - 18, 74 - 18). Аналогічні прийоми для випадків додавання та віднімання чисел, більших за 100, прийоми письмового додавання та віднімання, множення та ділення для випадків виду 14 × 5, 5 x 14, $81: 3,18$ x 40, $180: 20$. Такі ж прийоми множення та ділення для чисел, що більші за 100, та прийоми письмового множення та ділення (Бантова, 1993, с. 38-44).

Погоджуючись 3 М. Бантовою, до цього класу ми відносимо прийоми обчислень на підставі:

1) переставної властивості (закону) додавання, у випадку коли учні переставляють доданки за умов незручності додавання більшого числа до меншого $(2+8,5+8,7+12,8+26)$;

2) переставної властивості (закону) множення у випадку, коли учні переставляють множники за умов незручності множення більшого числа на менше (4 x 6, 5 x 14);

3) сполучної властивості (закону) додавання: правила додавання суми до числа $(6+3,8+5,14+9,23+25,67+18$, $730+240 \ldots)$, коли додавання здійснюється по частинах; правила додавання числа до суми $(14+9,23+25,67+18,730+$ 240 ...);

4) сполучної властивості (закону) множення: правила множення добутку на число (70 х 6, 200 х 6, 340 × 3) та числа на добуток (5 x 8, 6 × 70, 4 × 300, 7 $\mathrm{x} 120)$ - прийом послідовного множення;

5) правила віднімання числа від суми (27 - 8, 27 - 20, 36 - 28...);

6) правила віднімання суми від числа $(6$ - 4, 12 - 7, 54 - 8, 36 - 28, 430 - 170...) - прийом віднімання частинами;

7) розподільного закону множення відносно додавання: правила множення суми на число (23 х 6, 123 х 6) та числа на суму (6 x 23, 6 x 123);

8) розподільного закону ділення відносно додавання: правила ділення суми на число (42:3, $423: 3)$;

9) правила ділення числа на добуток $(810: 90,64: 16)$ - прийом послідовного ділення;

10) правила додавання суми до суми: порозрядне додавання $(45+32$, $45+37,460+230,460+270 \ldots)$;

11) правила віднімання суми від суми: порозрядне віднімання (67-25, 6729, 560-340, 510-340...);

12) письмові прийоми додавання та віднімання, множення та ділення.

Введенню прийомів, теоретичною основою яких $\epsilon$ зв'язок між взаємооберненими арифметичними діями (третя група), передує розгляд зв'язків взаємнообернених арифметичних дій 
- додавання та віднімання, множення та ділення. На цій основі і вводиться обчислювальний прийом (Бантова, 1993, с. 38-44). Доних М. Бантова відносить прийоми для випадків виду 9-7, 21 $: 3,60: 20,54: 18,9: 1,0: 6$, зазначаючи, що при їх введенні спочатку розглядаються зв'язки між компонентами та результатами відповідної арифметичної дії, а потім на цій підставі вводиться обчислювальний прийом.

До цього класу ми вслід за М. Бантовою відносимо наступні обчислювальні прийоми:

1) віднімання на підставі взаємозв'язку дій додавання і віднімання (9 - 7, 14 - 8);

2) віднімання на підставі означення арифметичної дії віднімання;

3) ділення на підставі взаємозв'язку дій множення та ділення $(21: 3,51: 17$, $60: 20)$;

4) ділення на підставі означення арифметичної дії ділення, у тому числі й ділення на двоцифрове число в межах 1000 ;

5) ділення на 1, у випадку коли учень застосовує правило множення числа 1 на будь-яке число;

6) ділення рівних чисел, у випадку коли учень застосовує правило множення числа 1 на будь-яке число;

7) ділення 0 на число, у випадку колу учень застосовує правило множення числа 0 на будь-яке число.

Прийоми, теоретичною основою яких є залежність результатів арифметичних дій від зміни одного 3 компонентів (четверта група), вимагають попереднього вивчення відповідних залежностей результату арифметичної дії від зміни одного з компонентів. До них належать прийоми округлення при додаванні і відніманні та прийоми множення та ділення на 5, 25 та 50 (Бантова, 1993, c. 38-44).

Наприклад: $24+78=24+80-2=104$ $-2=102$.

Тут ми застосовуємо правило: якщо один 3 доданків збільшиться на 2, то й сума збільшиться на 2. Щоб сума не змінилася, треба від отриманого результату відняти 2 . $3=19$.

Наприклад: $56-37=56-40+3=16+$

У даному разі застосовуємо таке правило: якщо від'ємник збільшити на 3 , то різниця зменшиться на 3. Щоб різниця не змінилася, треба до отриманого результату додати 3 .

Наприклад: 36 × $5=36$ × $10: 2=360$ : $2=180$.

Тут застосовується правило: якщо один із множників збільшити у 2 рази, то й добуток збільшиться у 2 рази. Щоб добуток не змінився, треба отриманий результат поділити на 2.

Аналогічно: $36 \times 50=36 \times 100: 2=$ $3600: 2=1800$;

$36 \times 500=36 \times 1000: 2=36000: 2=$ 18000 .

Якщо ділене закінчується нулями, то аналогічно можна виконувати ділення на $5,50,500$ :

$620: 5=620: 10 \times 2=62 \times 2=124$.

Туг застосовується правило: якщо дільник збільшити у 2 рази, то частка зменшиться у 2 рази. Тому, щоб частка лишилася незмінною, треба отриманий результат помножити на 2.

Аналогічно: $1300: 50=1300: 100 \times 2$ $=13 \times 2=26$; 166.

$$
83000: 500=83000: 1000 \times 2=83 \times 2=
$$

Однак цей прийом можна застосовувати не для всіх випадків, а лише тоді, коли в дільнику є достатня кількість нулів, щоб його поділити на розрядну одиницю.

Так само розглядається множення і ділення на 25, 250:

$32 \times 25=32 \times 100: 4=3200: 4=800$; 000 .

$56 \times 250=56 \times 1000: 4=56000: 4=12$

Туг застосовується правило: якщо один 3 множників збільшити в 4 рази, то й добуток збільшиться в 4 рази. Для того, щоб добуток не змінився, треба отриманий результат зменшити в 4 рази. Виконувати множення таким способом можна в будь-якому випадку, тому що при множенні його на 100 (1 000) отримаємо число, дві останні цифри якого утворюють число, що ділиться на 4. Але треба підбирати такий перший множник, щоб отриманий результат можна було усно поділити на 4.

При діленні на 25, 250 слід мати на увазі, що ділене повинно закінчуватися достатньою кількістю нулів:

$3100: 25=31: 100 ? 4=31 \times 4=124$; $76000: 250=76000: 1000 \times 4=76 \times 4=$ 304.

Туг застосовується правило: якщо дільник збільшимо в 4 рази, то частка зменшиться в 4 рази. Щоб частка не змінилася, треба результат збільшити в 4 рази.

При множенні на 25 можна міркувати інакше: 800 .

$32 \times 25=(32: 4) \times(25 \times 4)=8 \times 100=$

Тут застосовується правило: добуток не змінюється, якщо один множник зменшити в 4 рази, а інший, навпаки, збільшити в 4 рази. У цьому випадку слід підбирати такий множник, що ділитиметься на 4.

Уже в початковій школі учні повинні засвоїти такі правила:

1. Якщр фдин з доданків збільииmи/зменшити на декілька одиниць, а інший доданок залишити без змін, то сума збільшиться/зменшиться на стільки ж одиниць.

2. Якщо один з множників збільшиmи/зменшити в декілька разів, а інший множник залишити без змін, то добуток збільшиться/зменшиться у стільки ж разів.

3. Якщо один доданок збільшити/ зменшити на декілька одиниць, а інший доданок, навпаки, зменшити/ збільшити на стільки ж одиниць, то сума лишиться незмінною.

4. Якщо один множник збільиити/ зменшити в декілька разів, а інший множник, навпаки, зменшити/ збільшити у стільки ж разів, то добуток лишиться незмінним.

5. Якщо зменшуване більшити/ зменшити на декілька одиниць, а від'ємник залишити без змін, то різниця збільшиться/зменшиться на стільки ж одиниць.

6. Якщо ділене збільшити/зменши$m и$ в декілька разів, а дільник залишити без змін, то частка збільииться/зменшиться у стільки ж разів.

7. Якщо від'ємник збільшити/зменшити на декілька одиниць, а зменшуване залишити без змін, то різниця, навпаки, зменшиться/збільшиться на стільки ж одиниць.

8. Якщо дільник збільшити/змениити у декілька разів, а ділене залишити без змін, то частка, навпаки, зменииться/збільииться у стільки ж разів.

9. Якщо зменшуване збільиити/ зменшити на декілька одиниць, а від'ємник також збільшити/зменшити на стільки ж одиниць, то різниця не зміниться.

10. Якщо ділене збільшити/зменшити у декілька разів, а дільник також збільшити/зменшити в стільки ж разів, то частка не зміниться (Сквориова, \& Онопрієнко, 2019).

Прийоми, теоретична основа яких питання нумерації чисел (п'ята група), вводяться після вивчення відповідних питань нумерації: послідовності натуральних чисел, десятковий склад чисел, позиційний принцип запису чисел (Бантова, 1993, с. 40). До цього класу М. Бантова відносить прийоми для випадків виду а + 1, a - 1, 10+6, 16 - 10, 16 $-6,57$ x 10, 1200 : 100; аналогічні прийоми для більших чисел. Введення цих прийомів передбачається після вивчення відповідних питань нумерації 
(натуральної послідовності, десяткового складу чисел, позиційного принципу запису чисел).

Таким чином, у цей клас включимо обчислювальні прийоми:

1) додавання і віднімання числа 1 ;

2) додавання і віднімання на підставі десяткового складу чисел;

3) додавання і віднімання способом укрупнення розрядних одиниць;

4) множення і ділення на розрядну одиницю;

5) множення круглого числа на одноцифрове способом укрупнення розрядних одиниць;

6) ділення круглого числа на одноцифрове або ділення круглого числа на кругле способом укрупнення розрядних одиниць.

До прийомів, теоретичною основою яких є правила (шоста група), М. Бантова віднесла випадки множення на 0 та 1, оскільки правила множення чисел на 1 i $0 €$ наслідками з означення дій множення цілих невід'ємних чисел. Вони можуть безпосередньо повідомлятися учням, відповідно з ними виконуються обчислення. Також до цієї групи ми відносимо правила додавання i віднімання 3 числом 0 та правило віднімання рівних чисел.

1. Правило множення будь-якого числа на одиницю: при множенні будьякого числа на одиницю в добутку отримаємо те ж саме число.

a $1=\mathrm{a}$

2. Правило множення будь-якого числа на 0: при множенні будь-якого числа на нуль в добутку отримаємо нуль.

$$
\text { a } 0=0
$$

Як зазначалося вище, для окремого випадку обчислення можна застосувати кілька прийомів. Так, знаходження суми 36 і 19 можливе кількома способами:

1) частинами - на підставі правила додавання суми до числа:

$$
36+19=36+10+9=46+9=55 ;
$$$$
10+9
$$

$36+19=36+4+15=40+15=55$.

$4+15$

2) на підстави правила додавання числа до суми:

$36+19=30+6+19=(19+6)+30=$ $25+30=55$

$30+6$

$36+19=35+1+19=35+(1+19)=$ $35+20=55$.

$35+1$

3) порозрядне додавання - на підставі правила додавання суми до суми:

$36+19=30+6+10+9=(30+10)$

$+(6+9)=40+15=55$.

$30+6 \quad 10+9$

4) округлення - на підставі залежності суми від зміни одного $з$ доданків: 20

$36+19=36+20-1=56-1=55$.

Отже, способи обчислення 1-3 відповідають другій групі приймів (теоретичною основою яких $є$ властивості арифметичних дій), а спосіб 4 відноситься до четвертої групи прийомів (теоретичною основою яких є залежність результатів арифметичних дій від зміни одного 3 компонентів). Наприклад, при позатабличному діленні двоцифрового та трицифрового числа на двоцифрове можна застосувати або прийом на підставі конкретного змісту арифметичної дії ділення (перша група прийомів), або прийом послідовного ділення, заснований на правилі ділення числа на добуток (шоста група прийомів).

Аналогічні приклади можна навести до більшості випадків обчислення курсу математики початкової школи. Відповідно до сучасних тенденцій у математичній освіті робиться акцент на формування в учнів різних прийомів обчислення для того, щоб вони могли свідомо обрати спосіб обчислення, найзручніший для себе.

Висновки та перспективи подальших досліджень. Очевидно, що розглянуті прийоми пропонуються у курсі математики в певній послідовності, дотримуючись логіки розгортання змісту навчання. Так, у концентрі "Десяток" при виконанні обчислень школярі мають мати в арсеналі певні способи міркування: 1) вони можугь діяти на підставі знання складу числа і суті арифметичних дій додавання та віднімання (перша група прийомів); 2) при додаванні та відніманні числа 1 вони можуть діяти на підставі знання порядку слідування чисел у натуральному ряді (п'ята група прийомів); 3) при додаванні і відніманні чисел першої п'ятірки можуть виконати обчислення частинами (шоста група прийомів); 4) додавання чисел 6-9 можна здійснювати на підставі переставного закону додавання (друга група прийомів); 5) відняти числа 6-9 можна на підставі взаємозв'язку арифметичних дій додавання та віднімання (друга група прийомів). Окрім розглянугих нами обчислювальних прийомів, засвоєння більшості з яких є обов'язко- вими в курсі математики початкової школи, у перспективі наших досліджень вбачаємо необхідність розгляду ще й прийомів раціональних обчислень.

\section{СПИСОК ЛІТЕРАТУРИ}

Типові освітні програми для закладів загальної середньої освіти: 1-2 та 3-4 класи. (2019). Київ : Світоч.

Skvortsova, S., Romanyshyn, R. (2019). The Computational Activity of Younger Students: Neuropsychological Approach. Universal Journal of Educational Research, 7.12 2817-2829. Doi: 10.13189/ujer.2019.071232.

Скворцова, С. О., Онопрієнко, О. В. (2013). Математика. 2 клас. У 4 ч. (Ч. 14). Харків : Ранок.

Бантова, М. А. (1993). Система формирования вычислительных навыков.

Скворцова, С. О. (2003). Узагальнення усних прийомів додавання i віднімання під час вивчення теми "Повторення матеріалу" в 4 (3) класі.

Скворцова, С. О., Онопрієнко, О. В. (2019). Нова українська школа: методика навчання математики у 1-2 класах закладів загальної середньої освіти на засадах інтегративного і компетентнісного підходів. Харків : Ранок.

\section{REFERENCES}

Typical educational programs for general secondary education institutions: 1-2 and 3-4 grades. (2019). Kyiv : Svitoch Publishing House.

Skvortsova, S., Romanyshyn, R. (2019). The Computational Activity of Younger Students: A Neuropsychological Approach. Universal Journal of Educational Research 7.12 2817-2829. Doi: 10.13189/ur.2019.071232.

Skvortsova, S. O., Onoprienko, O. V. (2013). Mathematics. 2 grade. Kharkiv: Morning view.

Bantova, M. A. (1993). The System of formation of computation skills.

Skvortsova, S. O. (2003). Generalization of oral addition and subtraction techniques in the study of the topic "Revesion of material" in 4 (3) grade.

Skvortsova, S. O., Onoprienko, O. V. (2019). New Ukrainian School: Methods of Teaching Mathematics in Grades 1-2 of Secondary Education Establishments on the Basis of Integrative and Competency Approaches. Kharkiv : Morning Publishing House.

Стаття надійшла 20.03.2020 p. 